Article

\title{
Development and Characterization of Chitosan Microparticles-in-Films for Buccal Delivery of Bioactive Peptides
}

\author{
Patrícia Batista ${ }^{1}$, Pedro Castro ${ }^{1}$, Ana Raquel Madureira ${ }^{1}$, Bruno Sarmento ${ }^{2,3,4}$ () and \\ Manuela Pintado ${ }^{1, *}$ \\ 1 Escola Superior de Biotecnologia, Centro de Biotecnologia e Química Fina, Rua Arquiteto Lobão Vital, 172, \\ 4200-374 Porto, Portugal; pbatista@porto.ucp.pt (P.B.); pedro.joao.castro@gmail.com (P.C.); \\ rmadureira@porto.ucp.pt (A.R.M.) \\ 2 CESPU, Instituto de Investigação e Formação Avançada em Ciências e Tecnologias da Saúde, Rua Central de \\ Gandra 1317, 4585-116 Gandra-PRD, Portugal; bruno.sarmento@ineb.up.pt \\ 3 i3S-Instituto de Investigação e Inovação em Saúde, Universidade do Porto, Rua Alfredo Allen 208, \\ 4200-393 Porto, Portugal \\ 4 INEB-Instituto Nacional de Engenharia Biomédica, Universidade do Porto, Rua Alfredo Allen 208, \\ 4200-393 Porto, Portugal \\ * Correspondence: mpintado@porto.ucp.pt; Tel.: +351-225580097
}

Received: 17 January 2019; Accepted: 11 February 2019; Published: 20 February 2019

\begin{abstract}
Nowadays, bioactive peptides are used for therapeutic applications and the selection of a carrier to deliver them is very important to increase the efficiency, absorption, release, bioavailability and consumer acceptance. The aim of this study was to develop and characterize chitosan-based films loaded with chitosan microparticles containing a bioactive peptide (sequence: KGYGGVSLPEW) with antihypertensive properties. Films were prepared by the solvent casting method, while the microparticles were prepared by ionic gelation. The final optimized chitosan microparticles exhibited a mean diameter of $2.5 \mu \mathrm{m}$, a polydispersity index of 0.46 , a zeta potential of $+61 \mathrm{mV}$ and a peptide association efficiency of $76 \%$. Chitosan films were optimized achieving the final formulation of $0.79 \%$ $(w / v)$ of chitosan, $6.74 \%(w / v)$ of sorbitol and $0.82 \%(w / v)$ of citric acid. These thin $( \pm 0.100 \mathrm{~mm})$ and transparent films demonstrated good performance in terms of mechanical and biological properties. The oral films developed were flexible, elastic, easy to handle and exhibited rapid disintegration (30 s) and an erosion behavior of $20 \%$ when they came into contact with saliva solution. The cell viability (75-99\%) was proved by methylthiazolydiphenyl-tetrazolium bromide (MTT) assay with TR146 cells. The chitosan mucoadhesive films loaded with peptide-chitosan microparticles resulted in an innovative approach to perform administration across the buccal mucosa, because these films present a larger surface area, leading to the rapid disintegration and release of the antihypertensive peptide under controlled conditions in the buccal cavity, thus promoting bioavailability.
\end{abstract}

Keywords: bioactive peptides; buccal delivery; chitosan; microparticles; oral films

\section{Introduction}

In the last decade, protein and peptide delivery has become an important area of research for therapeutic applications [1-4]. Bioactive peptides are defined as specific protein fragments that have a positive impact on body functions or conditions, presenting many beneficial health effects (e.g., antimicrobial, antioxidant, antithrombotic and antihypertensive properties) [5,6]. The activity of bioactive peptides is based on their inherent amino acid composition and sequence. The peptide sequence KGYGGVSLPEW was identified in a whey protein hydrolysate and was recognized as a 
bioactive peptide with antihypertensive properties [7]. This peptide can be administered by parenteral route to avoid biological barriers that can hinder permeability. Nonetheless, the oral delivery of peptides and proteins remains an easier, more attractive and convenient alternative [8,9]. The buccal mucosa represents an important non-invasive alternative route for protein and peptide delivery, due to its ease of administration, evasion from the first pass hepatic metabolism, high relative permeability of many therapeutic agents and rich vascularization $[10,11]$.

However, a number of factors limit the absorption of peptides, due to their relatively large molecular size, physical/chemical barriers, involuntary swallowing of dosage forms and continuous dilution of dissolved molecules by saliva [2]. Indeed, the absolute buccal bioavailability levels of most peptides and proteins are less than $1 \%[6,12,13]$. So, numerous approaches have been attempted with the aim of improving the permeability of peptides. The development of delivery systems such as micro/nanoparticles (MPs/NPs) and their use as carriers coupled to other systems represents a valid approach to overcome these drawbacks. Such systems have attracted growing scientific and commercial attention as bioactive protein/peptide carriers during the last few years [6,14]. The encapsulation of bioactive peptides presents many advantages, such as improved efficiency and absorption, enhanced protection from enzymatic and $\mathrm{pH}$ degradation, controlled release of loaded peptide, increased bioavailability and enhanced patient compliance $[10,14,15]$. The development of nano/micro carriers and the use of the buccal route for mucosal (local) and transmucosal (systemic) delivery of therapeutic macromolecules is an interesting and promising combination. The association of mucoadhesive oral films with MPs/NPs represents a promising strategy to overcome these obstacles [10].

In the development of these delivery systems, polymers are often used as a matrix for peptide loading. Thus, chitosan $(\mathrm{CH})$ was chosen as the polymer to be used, because previous studies have shown it to possess diverse biological activities, including biocompatible, biodegradable, non-toxic, antihypertensive, anti-inflammatory and antimicrobial properties, and it has shown great potential in applications of drug delivery [14,16-19]. Chitosan is a mucoadhesive polymer due to its ability to form ionic, $\mathrm{pH}$-dependent interactions with mucin and its ability to enhance the penetration of large molecules across the mucosal surface. Therefore, it is a good candidate for buccal delivery $[20,21]$. So, chitosan has attracted attention as a potential food preservative of natural origin and was approved by the United States Food and Drug Administration (USFDA) as a Generally Recognized as Safe (GRAS) food additive and as a delivery system to the human body, more specifically as an oral delivery system [22].

This paper reports the development and characterization of chitosan microparticles loaded with an antihypertensive peptide with subsequent incorporation into chitosan films, aiming to achieve the administration of peptides across the buccal mucosa. This delivery system (film-MPs) is interesting because the mucoadhesive films administered to the mucosal surface could represent a delivery device with multifunctionalities such as mucoadhesion, control release and drug protection by avoiding or reducing passage through the gastrointestinal tract, and a conveyor system of MPs with bioactive peptides. The MPs exert their function by protecting the bioactive peptides from degradation and acting as a controlled release system because chitosan mucoadhesive properties are able to promote enhanced bioactive molecules delivery.

This study intends to have an impact on the nutraceutical and pharmaceutical industry. The development of an oral film incorporating microparticles enhances the advantages of oral films in terms of administration (reported in many studies) with the controlled delivery. The fact that the transported molecule is a peptide resulting from whey protein hydrolysate enhances its nutritional value and associated therapeutic potential. Therefore, this new delivery system may prove to be an enhancer of controlled release delivery of bioactive molecules with potential therapeutic effect, although clinical studies are needed. 


\section{Materials and Methods}

\subsection{Materials and Cell Line}

KGYGGVSLPEW peptide was purchased from GenScript (Piscataway, USA). Low-molecularweight chitosan (50,000-190,000 Da, 75-85\% of deacetylation), ethyl acetate, pentasodium tripolyphosphate (TPP), $\alpha$-amylase, pepsin, bovine bile salts, pancreatin, trifluoroacetic acid (TFA) and D-sorbitol (assay purity $\geq 98 \%$ ) and phosphate-buffered saline tablets (PBS) were purchased from Sigma-Aldrich (Steinheim, Germany). Citric acid monohydrate, potassium phosphate monobasic anhydrous and sodium phosphate dibasic were obtained from Merck (Darmstadt, Germany). Sodium chloride was purchased from Panreac (Barcelona, Spain). Glacial acetic acid, sodium hydroxide and all other chemicals were of analytical grade, purchased from Sinopharm Chemical Reagent Co., Ltd., Shanghai, China. Methanol and acetonitrile (HPLC gradient grade) were purchased from Fisher (Loughborough, UK). Ultrapure water was used to prepare all formulations.

TR146 cell line was purchased from Sigma-Aldrich (Stenheim, Germany). Fetal bovine serum (FBS), HAMS-F12 culture medium and Pen-Strep (10,000 U Penicillin, 10,000 U Streptomycin) were purchased from Lonza ${ }^{\circledR}$ (Verviers, Belgium). TrypLE ${ }^{\mathrm{TM}}$ express was purchased from Gibco ${ }^{\circledR}$ (Taastrup, Denmark). Thiazolyl Blue Tetrazolium Bromide (MTT) was purchased from VWR (Solon, USA). Dimethyl sulphoxide (DMSO) 99.7\% was purchased from Fisher Bioreagents ${ }^{\mathrm{TM}}$ (Pennsylvania, USA). Lastly, 96-well plates were purchased from Thermo Scientific (Hvidovre, Denmark).

\subsection{Formulation of Chitosan Microparticles Loaded with the Antihypertensive Peptide}

Chitosan microparticles (CH MPs) were prepared by the ionic gelation method of chitosan with TPP [23]. Chitosan solutions were prepared by dissolving $40 \mathrm{mg}$ of chitosan $(0.4-0.1 \mathrm{M})$ in $2 \mathrm{~mL}$ of a $1 \%(v / v)$ glacial acetic acid solution [24]. Afterwards, the peptide was dissolved in the chitosan solution and $1.5 \mathrm{mg}$ of TPP (cross-linker) was added and left under magnetic stirring at $1000 \mathrm{rpm}$ for $90 \mathrm{~min}$ at room temperature. Microparticles were formed spontaneously upon the incorporation of TPP into the $\mathrm{CH}$ solution.

\section{Preliminary Optimization and Factorial Design}

Experimental design for chitosan microparticles was performed using SAS JMP ${ }^{\circledR} 9$ software [25]. Factorial design allowed all the factors to be varied simultaneously, enabling the evaluation of the effects of each variable at each level and showing the interrelationship among them. The number of experiments required for these studies was dependent on the number of independent variables selected. Each design was performed considering five dependent variables (size, zeta potential, polydispersity index (PDI), association efficiency and loading degree) as well as two independent variables (polymer and TPP concentration). Every response test was performed in triplicate. When responses were determined, independent variables that influenced the behavior of evaluated dependent variables were selected for the elaboration of the predictive statistic model, according to RSquare and RSquare adjusted values. Finally, optimal formulations for each polymer were obtained by maximizing desirability values.

\subsection{Characterization of Chitosan Microparticles}

After production, MPs were characterized for their mean particle size and PDI by dynamic light scattering. Zeta potential was determined by phase analysis light scattering. All measurements were performed using a Malvern Zetasizer Nano ZS instrument (Malvern Instruments Ltd., Malvern, UK). For these measurements, samples were diluted in saline solution. 


\subsection{Association Efficiency and Loading Degree}

The CH MPs association efficiency was determined upon the separation of MPs from the aqueous preparation medium containing the non-associated protein by centrifugation $\left(15,000 \times g, 45 \mathrm{~min}, 15^{\circ} \mathrm{C}\right)$. The amount of free peptide was determined in the supernatant by a HPLC-UV (Waters Alliance ${ }^{\circledR}$ instrument (Milford, MA, USA)) method. In this method, a Kromasil ${ }^{\circledR} \mathrm{C} 18$ column (AkzoNobel, Bohus, Sweden) was used and the UV detector wavelength was set to $280 \mathrm{~nm}$. The mobile phases consisted of acetonitrile and $0.1 \%$ TFA, and water and $0.1 \%$ TFA. The ratio was initially set at the ratio of 80:20 (acetonitrile: $0.1 \%$ TFA, $v / v$ ), which linearly changed to a 40:60 (v/v) gradient over $10 \mathrm{~min}$. The flow rate was $0.8 \mathrm{~mL} / \mathrm{min}$ and the injected volume of the sample was $20 \mu \mathrm{L}$. The UV detector wavelength was set at $280 \mathrm{~nm}$. The total area under the peak was used to quantify the KGYGGVSLPEW peptide sequence. Each sample was assayed in triplicate $(n=3)$. The CH MPs peptide association efficiency (AE) and loading degree (LD) were calculated as follows (Equations (1) and (2)):

$$
\begin{aligned}
& A E(\%)=\frac{\text { total peptide amount }- \text { free peptide amount }}{\text { total peptide amount }} \times 100, \\
& L D(\%)=\frac{\text { total peptide amount }- \text { free peptide amount }}{\text { peptide loaded CH MPs dry weight }} \times 100,
\end{aligned}
$$

\subsection{Preparation of Chitosan Oral Films}

Chitosan films were prepared by the solvent casting method with some modifications [26]. The composites $(78.6 \mathrm{mg}$ chitosan $(0.15-0.04 \mathrm{M}), 82.5 \mathrm{mg}$ of citric acid $(0.039 \mathrm{M})$ and $674 \mathrm{mg}$ of sorbitol $(0.37 \mathrm{M})$ ) were added to $10 \mathrm{~mL}$ of deionized water. The mixture was covered and stirred (magnetic stirring, $300 \mathrm{rpm}$, at room temperature for $120 \mathrm{~min}$ ) until chitosan was totally dissolved. Subsequently, the solution $(10 \mathrm{~mL})$ was dispensed into Petri dishes $(90 \times 15 \mathrm{~mm})$ and dried for $48 \mathrm{~h}$ in an incubator set to $30^{\circ} \mathrm{C}$. After drying, films were then cut into squares $(2 \times 2 \mathrm{~cm})$.

\section{Chitosan Films Experimental Design Testing}

The experimental design employed SAS JMP ${ }^{\circledR} 9$ software (JMP Statistical Discovery ${ }^{\mathrm{TM}}$, Marlow, UK), using a similar procedure to that described in microparticles section. Each design was performed considering five dependent variables: elongation at break, tensile strength, Young's modulus, water uptake and erosion. For each polymer tested, three independent variables were considered (polymer concentration (chitosan $0.5,1,1.5(\%, w / v))$, plasticizers (sorbitol) concentration $(32.5,56.3,75 \mathrm{mg} / \mathrm{mL}$ ) and citric acid concentration $(7.5,10,12.4 \mathrm{mg} / \mathrm{mL})$ ). Citric acid was used to induce the production of saliva in order to promote the disintegration of oral films the oral cavity [15]. Sorbitol concentration was stipulated according to polymer dry weight.

Each sample was tested in triplicate $(n=3)$. When the results were obtained, a screening design was executed, and independent variables that influenced the behavior of the evaluated dependent variables were selected for the elaboration of the predictive statistic model (with RSquare and RSquare adjusted values). Thus, optimal formulations were obtained by setting desirability values to each response type to obtain maximum desirability.

\subsection{Chitosan Films Characterization}

\subsubsection{Film Appearance}

The appearance of films was evaluated by visual observation using parameters such as the transparency and semi-transparency nature of the strip [26]. 


\subsubsection{Film Weight and Thickness}

Films strips were weighed on a calibrated analytical scale and the thickness was measured using a calibrated Vernier gauge caliper micrometer [15].

\subsubsection{Determination of the Mechanical Properties}

The main mechanical properties such as tensile strength (MPa), strain at tensile strength (\%), Young's modulus and strain energy (MPa) (Equations (3) and (4), respectively) were evaluated. For that purpose, the developed films were cut in squares $(2 \times 2 \mathrm{~cm})$ and these properties were measured using a texturometer (TA.XT plus Texture Analyser, Stable Micro Sydtems, Cardiff, UK) [15]. All measurements were performed in three films for each formulation.

$$
\begin{gathered}
\text { Young's modulus }(\mathrm{MPa})=\frac{\text { Force at corresponding strain }}{\text { Cross }- \text { sectional area of the film } \times \text { Corresponding strain }} \times 100, \\
\text { Strain Energy }(M P A)=\frac{1}{2} \times \frac{\text { volume }}{\text { Young'smodulus }} \times \text { Stress }^{2},
\end{gathered}
$$

\subsubsection{Swelling and Erosion Studies}

Plain films were characterized for their swelling properties and erosion features by calculating the percentage of hydration and matrix erosion of the films. Films $(2 \times 2 \mathrm{~cm})$ were cut and weighed $\left(W_{0}\right)$. Subsequently, films were immersed in the artificial salivary solution $(\mathrm{pH} 6.8)$ for a consecutive series of $30 \mathrm{~s}$ each, over $1 \mathrm{~min}$. At these time intervals, the films were wiped off using filter paper and weighed $\left(W_{1}\right)$. The swelling of the films was determined using the following relation (Equation (5)):

$$
\text { Swelling }(\%)=\frac{W_{1}-W_{0}}{W_{0}} \times 100,
$$

where $W_{1}$ is the weight of swollen film after time $t$ and $W_{0}$ is the weight of the film at time zero.

After complete hydration, films were dried at $37^{\circ} \mathrm{C}$ for $24 \mathrm{~h}$. The dried films were taken and their weight was registered $\left(W_{2}\right)$. Erosion was calculated using the following relation (Equation (6)):

$$
\text { Erosion }(\%)=\frac{W_{1}-W_{2}}{W_{1}} \times 100,
$$

where $W_{1}$ is the weight of swollen film after time $t$ and $W_{2}$ is the weight of dry film after erosion.

\subsection{Chitosan Films with Chitosan Microparticles}

Chitosan MPs $(0.4-0.1 \mathrm{M})$ were incorporated into $\mathrm{CH}$ film solutions $(15.7 \mathrm{mg}$ of chitosan $(0.157-0.041 \mathrm{M}), 16.5 \mathrm{mg}$ of citric acid $(0.039 \mathrm{M})$ and $134.8 \mathrm{mg}$ of sorbitol $(0.37 \mathrm{M})$ in $2 \mathrm{~mL}$ of deionized water for $30 \mathrm{~min}$ in order to uniformly disperse MPs. The $\mathrm{CH}$ films with $\mathrm{CH}$ MPs were prepared by the solvent casting method.

Chitosan films with $\mathrm{CH}$ MPs were poured on Petri dishes and placed to dry for $48 \mathrm{~h}$ in an incubator at $37^{\circ} \mathrm{C}$. After drying, films were cut into squares $(2 \times 2 \mathrm{~cm})$. Each formulated film was prepared in triplicate.

\subsection{Cell Culture}

Cell culture systems are important for the examination the biological properties, such as the bioavailability or toxicity of bioactive molecules. The TR146 cell culture model was selected as an in vitro model of the human buccal epithelium. The TR146 cell line originated from a human buccal carcinoma. After culturing, the TR146 cell line forms a stratified epithelium similar to the buccal epithelium $[27,28]$. 
The TR146 cells were grown in HAMS F-12 Medium with supplements of 10\% $(v / v)$ fetal bovine serum (FBS) and $1 \%(v / v)$ antibiotic/antimitotic mixture (final concentration of $100 \mathrm{U} / \mathrm{mL}$ penicillin and $100 \mathrm{U} / \mathrm{mL}$ streptomycin). Culture conditions were maintained at $37{ }^{\circ} \mathrm{C}, 5 \% \mathrm{CO}_{2}$ and $95 \%$ relative humidity. Sub-cultivation was performed at approximately $80 \%$ confluence with $0.25 \%$ trypsin-EDTA to detach the cells from the flasks. Cells were then seeded at a density of $1 \times 10^{6}$ cells per $75 \mathrm{~cm}^{2}$ flask. The culture medium was replaced every other day. Cells were maintained in an incubator (BB 16 gas incubator, Heraeus Instruments $\mathrm{GmbH}$ ) at $37^{\circ} \mathrm{C}, 5 \% \mathrm{CO}_{2}$ and $95 \%$ relative humidity.

\section{Cell Viability Studies}

The cell viability of TR146 cell line, after $24 \mathrm{~h}$ treatment with $\mathrm{CH}$ MPs, $\mathrm{CH}$ films, with or without peptide (with concentration $5 \mu \mathrm{g} / \mathrm{mL}$ ), was measured using the methylthiazolydiphenyl-tetrazolium bromide conversation (MTT) assay [23].

Cells were seeded in 96-well plates at $2 \times 10^{5} /$ well in $300 \mu \mathrm{L}$ culture medium and incubated for $24 \mathrm{~h}$ at $37{ }^{\circ} \mathrm{C}$ in a $5 \% \mathrm{CO}_{2}$ environment. The medium was then changed and the cells were treated with test samples (peptide, $\mathrm{CH}$ MPs, $\mathrm{CH}$ MPs with peptide; $\mathrm{CH}$ films; $\mathrm{CH}$ films with peptide; $\mathrm{CH}$ films with MPs with peptide or free) for $24 \mathrm{~h}$. Each treatment was tested in six individual wells. After $24 \mathrm{~h}$, the supernatant was removed and $200 \mu \mathrm{L}$ of MTT solution $(5 \mathrm{mg} / \mathrm{mL}$ in the cellular culture medium) was added to each well of the 96-well plates. They were then incubated for $4 \mathrm{~h}$ at $37^{\circ} \mathrm{C}$ to allow the formation of formazan crystal. The medium was then removed, and the blue formazan was eluted from cells using $150 \mu \mathrm{L}$ of DMSO. The negative control used was also DMSO. The plates were shaken on an orbital shaker to solubilize the crystals of formazan. The dark blue crystals were aspirated to another new 96-well microplate and the optical density (OD) was measured directly in the microplate reader at 570 and $690 \mathrm{~nm}$ for background reduction. All samples were tested for $n=5$ experiments with comparable results.

The cell viability of the tested delivery systems was calculated from the average OD values (Equation (7)).

$$
\text { Cell viability }(\%)=\frac{O D \text { value of specimen suspension }}{O D \text { value of negative control suspension }} \times 100,
$$

\subsection{Statistical Analysis}

Statistical analysis was performed using SPSS ${ }^{\circledR}$ for Windows version 22 (IBM SPSS, Chicago, IL). The average percentage of peptide released from $\mathrm{CH}$ films was calculated for each time point, along with respective standard deviation values.

The $t$-test was used to verify the existence of statistically significant differences between predictive models and experimental results. Chitosan MPs experimental data were obtained from three samples and the mean values were compared with the values predicted in the model.

Prediction formulas that describe the statistically significant influence of independent variables on dependent variables were obtained using SAS JMP ${ }^{\circledR}$ software. From the analysis of RSquared and adjusted RSquared, the best models were chosen and prediction formulas were obtained. From the predictive models, predictive profilers were obtained and optimal formulations were determined for each formulation of the $\mathrm{CH}$ oral film.

\section{Results and Discussion}

\subsection{Preparation and Characterization of Chitosan Microparticles}

Chitosan MPs were prepared by the ionic gelation method by auto-aggregation between a positively charged amino group of chitosan and the negatively charged phosphate groups of TPP (cross-linking agent) $[19,29,30]$. Chitosan MPs cross-linked with TPP have been employed in many studies for drug delivery systems because TPP is used to improve the mechanical properties 
and stability of CH MPs [8,29]. The parameters, type of cross-linking agent and polymer were optimized in preliminary studies. The $\mathrm{CH}$ MPs optimized formulation was set as $40 \mathrm{mg}$ chitosan (polymer) and $1.5 \mathrm{mg}$ TPP (cross-linker). Figure 1 outlines the factorial design and values of the formulation parameters.

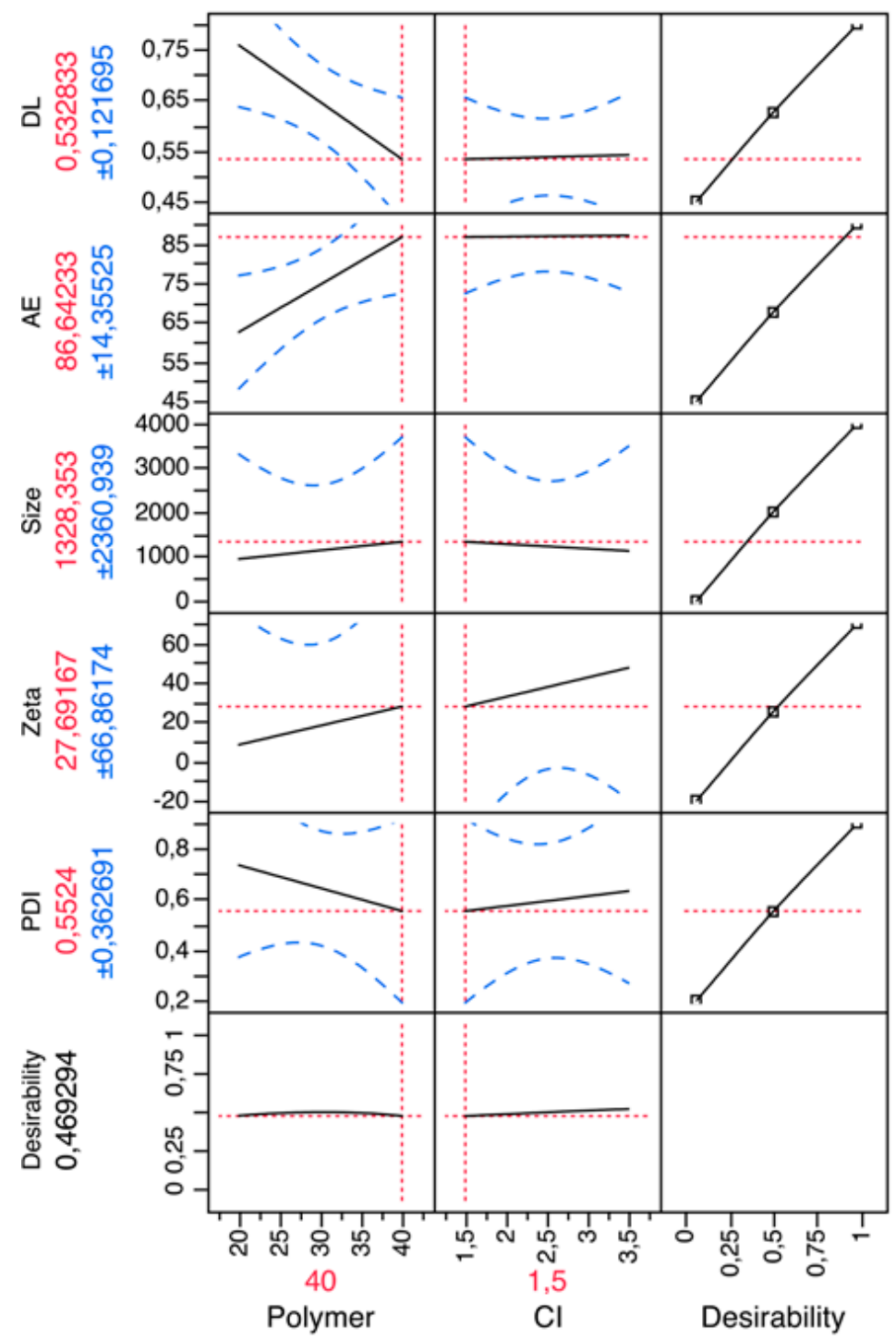

Figure 1. Prediction profiler for chitosan $(\mathrm{CH})$ microparticles (MPs). X-axis: polymer $(\mathrm{CH})(\mathrm{mg})$, counter-ion (TPP) (mg); Y-axis: polydispersity index (PDI), zeta potential (mV), size (nm), association efficiency (AE), drug loading (DL).

In order to achieve theoretical optimization to validate the results, the formulations of $\mathrm{CH}$ MPs were further assessed for mean size, polydispersity index, zeta potential and association efficiency. The obtained results were individually compared with the theoretical (predicted) values by Student $t$-tests. No statistically differences $(P>0.05)$ were found between predicted and experimental values.

After the optimization of the $\mathrm{CH}$ MPs, peptide-loaded $\mathrm{CH}$ MPs were prepared and parameters such as particle size, zeta potential, PDI, association efficiency and loading capacity were analyzed because those properties are important for therapeutic properties.

The mean size of $\mathrm{CH}$ MPs is dependent on both chitosan molecular weight and concentration and on TPP concentrations. Particle size can influence the biopharmaceutical properties of microparticles, their biodistribution and the particle content uptake [8,31]. Particle size was the leading assessed 
property during formulation optimization studies, oriented towards obtaining microparticles with a mean diameter of about $2.5 \mu \mathrm{m}$ with a reproducible size distribution. As shown in Table 1, unloaded CH MPs presented a size of $2.544 \pm 0.97 \mu \mathrm{m}$ and peptide-loaded $\mathrm{CH}$ MPs had a size $2.582 \pm 0.87$ $\mu \mathrm{m}$. The determined size of chitosan microparticles was in agreement with results reported in the literature [32].

Peptide loading by the encapsulation method did not induced an increase in particle size when compared with empty CH MPs (Table 1). So, the incorporation of the peptide into CH MPs did not have a significant effect on particle size.

Table 1. Characteristics of unloaded $\mathrm{CH}$ MPs and peptide-loaded $\mathrm{CH}$ MPs (CH MPs + peptide) (mean $\pm \operatorname{sd}(n=3))$.

\begin{tabular}{cccccc}
\hline Caption & Size $(\boldsymbol{\mu m})$ & $\begin{array}{c}\text { Polydispersity } \\
\text { Index }\end{array}$ & $\begin{array}{c}\text { Zeta Potential } \\
(\mathbf{m V})\end{array}$ & $\begin{array}{c}\text { Association } \\
\text { Efficiency (\%) }\end{array}$ & $\begin{array}{c}\text { Loading } \\
\text { Capacity (\%) }\end{array}$ \\
\hline CH MPs & $2.544 \pm 0.97$ & $0.66 \pm 0.18$ & $50.38 \pm 7.18$ & - & - \\
\hline CH MPs + Peptide & $2.582 \pm 0.87$ & $0.45 \pm 0.18$ & $60.97 \pm 9.20$ & $76.16 \pm 1.96$ & $0.46 \pm 0.01$ \\
\hline
\end{tabular}

The particle size and surface charge of MPs/NPs regulate the biodistribution and pharmacokinetic properties of the MPs/NPs in the body. Therefore, the zeta potential is another important parameter and useful indicator of the electronic charge, which can be used to predict and control the stability of colloidal suspensions or emulsions [8,31]. The greater the zeta potential, the more likely the suspension is to be stable because the charged particles repel one another and thus overcome the natural tendency to aggregate. Microparticles with a zeta potential above $\pm 30 \mathrm{mV}$ have been shown to be stable in suspension, as the surface charge prevents the aggregation of the particles [33]. According to the results obtained (Table 1), all the batches prepared showed a zeta potential more than $+30 \mathrm{mV}$, confirming that microspheres exhibited good stability and no aggregation in the suspension. The positive value of the zeta potential might be due to the positive charge of chitosan and the high positive zeta potential indicated that the electrostatic repulsion between particles prevented aggregation and increased their stability. The positive value of the zeta potential is important for buccal drug delivery since it can facilitate adhesion to the mucosal epithelial surface, thus prolonging the peptide release and enhancing the peptide bioavailability. The results showed that the addition of peptide has no significant effect on the microparticles zeta potential.

The PDI values of CH MPs and peptide-loaded CH MPs were around 0.5 (the index is a measure of dispersion homogeneity; values closer to zero indicate a homogeneous dispersion), indicating uniformity of particle size and monodispersity distribution, with low variability and no aggregation, as reported in the literature [30,34]. If a scale from 0 to 1 is considered, a PDI lower than 0.1 might be associated with a high homogeneity in the particle population, whereas high PDI values suggest a broad size distribution or even several populations. The calculation of PDI takes into account the mean particle size, the refractive index of the solvent, the measurement angle and the variance of the distribution. So, the PDI affects the mechanical strength of the polymer and its ability to be formulated as a delivery device, and these properties may control the polymer biodegradation rate [35].

Association efficiency and loading capacity are other characteristics that should be calculated for controlled delivery systems [8]. The association of bioactive peptides with the delivery systems components conditions the delivery system success, because it can protect biomolecules against metabolic degradation and improve protein absorption into the intestinal epithelium with better bioavailability. $\mathrm{CH}$ MPs were successfully prepared via the ionic gelation method and ensured encapsulation of the peptide. Although the association efficiency of hydrophilic molecules is usually low, in this study we obtained high encapsulation efficiency values, similar to other studies. Table 1 shows the association efficiency and loading capacity of peptide-loaded $\mathrm{CH}$ MPs. The CH MPs with peptide showed an encapsulation efficiency of $76 \%$, achieving a particle loading degree of $0.46 \%(n=3)$. The antihypertensive peptide was successfully entrapped into the CH MPs with a high association 
efficiency, indicating the good potential of CH MPs as a delivery system. The AE was optimized by varying some parameters, including the amount of chitosan and TPP concentrations. The AE and size are important indexes for evaluating the quality of delivery systems. The high $\mathrm{AE} \%$ can improve the utilization of the peptide and a smaller size could enhance the absorption of buccal cells [36,37]. Indeed, other authors $[33,36,38]$ have already proven that $\mathrm{CH}$ MPs are natural materials with excellent physicochemical properties, good carriers for encapsulating proteins, which can achieve high protein loading efficiency and protect them from degradation.

\subsection{Chitosan Films Characterization}

Various methods have been described in the literature as appropriate to prepare $\mathrm{CH}$ films for delivery systems [26]. The solvent casting method was selected because it is the method most commonly reported in the literature due to its inherent simplicity and robustness. It is a feasible and cost-effective technique which ensures greater commercial viability.

Firstly, a $\mathrm{CH}$ film experimental design was performed in order to obtain optimized formulations and understand how excipients influence the mechanical characteristics of the films. Figure 2 shows the prediction profilers used in the optimization of the formulations of $\mathrm{CH}$ films.

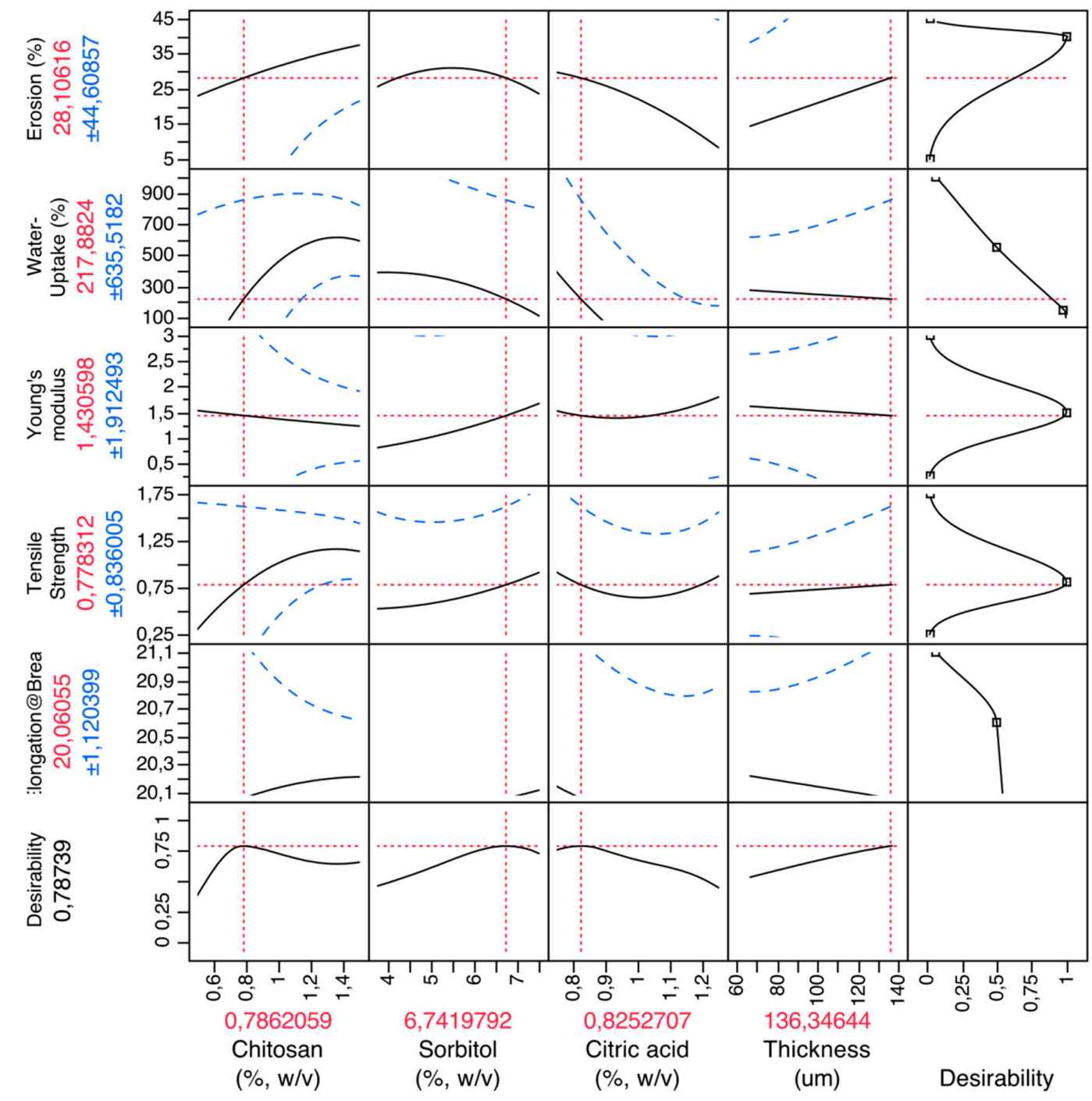

Figure 2. Prediction profiler for $\mathrm{CH}$ films. X-axis: excipients (chitosan, sorbitol, citric acid) and thickness; Y-axis: mechanical properties (elongation at break (\%), tensile strength (MPa), Young's modulus (MPa)), water uptake (\%) and erosion (\%). 
By setting the desirability of dependent variables to maximum, it was possible to obtain the best possible formulations. So, the optimized formulation of the $\mathrm{CH}$ films was set as $0.79 \%(w / v)$ of chitosan (polymer), $6.74 \%(w / v)$ of sorbitol (plasticizer), $0.82 \%(w / v)$ of citric acid (salivary stimulator) and an ideal thickness of $136 \mu \mathrm{m}$.

Chitosan is commonly used for producing MPs/NPs thanks to their excellent properties (biocompatible, biodegradable, non-toxic, antihypertensive, anti-inflammatory, antimicrobial, mucoadhesive). However, the properties of these carriers can be further improved by the addition of plasticizers; for example, in this case sorbitol was used. The plasticizer molecules interposing between the polymer chains and interacting with their functional groups increased polymer chain mobility and flexibility and improved mechanical properties. Specifically, they reduced brittleness, improved flow, imparted flexibility and increased the toughness of films [17].

For the preparation of the films, citric acid was also added as a saliva stimulating agent [26]. The purpose of using citric acid is to increase the rate of production of saliva, which would aid in the faster disintegration and consequently the rapid dissolution of the film.

After optimized $\mathrm{CH}$ films composition, the films were produced at the same time as $\mathrm{CH}$ MPs. That way, the constituents of the films were added to the microparticle solution. Finally, the final solution was dried at room temperature and the optical and morphological properties were evaluated. These films were transparent, flexible and homogeneous, and their surfaces appeared to be smooth without pores and cracks [39,40]. The films were thin, with a thickness ranging between 0.085 and $0.117 \mathrm{~mm}$, evaluated using a digital Vernier caliper [40]. The thickness, flexibility, elasticity and easy handling are important properties for oral films application and consumer acceptance [17]. So, we needed to evaluate mechanical properties: the elastic modulus, to evaluate the film's rigidity; the tensile strength, to determine the brittleness of the film; the elongation at break, to know the flexibility and elasticity. These properties needed to be investigated as they condition the film's integrity and its performance [38]. The Young's modulus, tensile strength and elongation at break were measured and are shown in Table 2.

Table 2. Mechanical properties of $\mathrm{CH}$ films incorporated with peptide-loaded $\mathrm{CH}$ MPs.

\begin{tabular}{cccc}
\hline Caption & $\begin{array}{c}\text { Young's Modulus } \\
\text { (MPa) }\end{array}$ & $\begin{array}{c}\text { Tensile Strength } \\
\text { (MPa) }\end{array}$ & $\begin{array}{c}\text { Elongation at Break } \\
\text { (\%) }\end{array}$ \\
\hline CH MPs & $2.12 \pm 0.93$ & $0.71 \pm 0.09$ & $20.06 \pm 0.68$ \\
\hline CH MPs + Peptide & $2.29 \pm 0.81$ & $0.77 \pm 0.09$ & $20.27 \pm 0.72$ \\
\hline
\end{tabular}

The tensile strength is an important mechanical property to avoid damage (release of the carrier molecule) during post-production storage and transporting. Basically, this test is performed to measure of the maximum strength of a film to withstand applied tensile stress, and the percent elongation represents the ability of a film to stretch [41]. In optimized $\mathrm{CH}$ films, the tensile strength obtained was $0.767 \pm 0.091(\mathrm{MPa})$. This result is very low when compared with the tensile strength of the pure $\mathrm{CH}$ film in other studies, such as $8 \mathrm{MPa}$ [41], $10.97 \mathrm{MPa}$ [40] and $98 \mathrm{MPa}$ [39]. The different results may be due to differences in chitosan type, plasticizer presence, film formation method or analytical methods used $[39,40]$.

Another mechanical property is the Young's modulus, which is an indicator of the stiffness (rigidity) of the film. It is reported to offer a sharp burst release of carrier molecules. The elongation at break is an indicator of its extensibility. The Young's modulus for $\mathrm{CH}$ films incorporated with peptide-loaded $\mathrm{CH}$ MPs are higher than $\mathrm{CH}$ films (Table 2), because the Young's modulus increased with the increase of filler content [42], but no statistically significant differences $(P>0.05)$ were found. The values obtained were low when compared with those of other oral films [43], but the composition and the evaluation methods were not the same. The low Young's modulus obtained in our films indicates softer networks, lower water sorption and higher solubility. 
The tensile strength and elongation at break values obtained for the peptide-loaded CH MPs indicate that the incorporation of the peptide into the films did not significantly alter the tensile strength compared with that of uncoated films, corroborating the findings of Aguilar and collaborators [44].

Films were also analyzed regarding disintegration capacity. Effectively, orodispersible films have a high delivery potential because when placed on the tongue, they are immediately hydrated by saliva, followed by disintegration and/or dissolution and the release of the bioactive peptide [45]. This $\mathrm{CH}$ film with peptide-loaded CH MPs, when contacted with saliva solution, showed a quickly swelling $(217.05 \pm 122.36 \%)$ and erosion $(17.25 \pm 12.21 \%)$ due to the disentanglement of the loosely bound chitosan molecules, which allowed a facile diffusion of the peptide-loaded CH MPs from the matrix (see Table 3) [46]. The swelling of the films first increased dramatically due to the porous structure and the hydrophilicity of the $\mathrm{CH}$ film, indicating a strong hydration of chitosan, which facilitates the rapid mucoadhesion to the absorptive epithelia [46]. Mucoadhesion occurs when the $\mathrm{CH}$ film comes in contact with buccal epithelial cells; a double layer of electrical charge forms at the interface to promote the adhesion [46]. The data obtained in this study confirm other reports in the literature; that is, the optimized $\mathrm{CH}$ film provides rapid disintegration (30 s) and the release of actives when the strip comes into contact with saliva in the mouth. These results agree with the range of values indicated by the Guidance for Industry [47,48].

Table 3. Swelling and erosion behavior of $\mathrm{CH}$ films incorporated with peptide-loaded $\mathrm{CH}$ MPs.

\begin{tabular}{ccc}
\hline Erosion (\%) & Swelling (\%) & Disintegration Time (s) \\
\hline $20.03 \pm 1.3$ & $257 \pm 56$ & 30 \\
\hline
\end{tabular}

\subsection{In Vitro Cell Viability}

In addition to the preparation and characterization, the in vitro evaluations of $\mathrm{CH}$ films with peptide-loaded CH MPs are important for understanding the behavior of these delivery systems in biological systems, as well as for elucidating the nature of interaction between the delivery system and tissues, i.e., the biocompatibility. Among the biocompatibility tests, cytotoxicity is preferred as it is simple, fast and has a high sensitivity. The cytotoxicity test is one of the most important methods for biological evaluation. In order to evaluate the cytotoxicity of developed formulations, the MTT assay was performed. The effect of $\mathrm{CH}$ films with peptide-loaded CH MPs on TR146 cells was tested in vitro.

Cytotoxicity ratios and viability were classified according to the following criteria for cytotoxicity: (a) if viability $>100 \%$, the corresponding cytotoxicity type was class 0 , indicating no toxicity; (b) if viability $=0 \%$, the corresponding cytotoxicity type was class 5 , indicating the highest toxicity; (c) $75-99 \%, 50-74 \%, 24-49 \%$ and $1-25 \%$ viability were categorized as classes $1,2,3$ and 4 , respectively [49].

Figure 3 outlines the results obtained from the MTT assay of TR146 cells after being exposed to developed formulations for a period of $24 \mathrm{~h}$. The results indicat that all experimental conditions $(\mathrm{CH}$ MPs; peptide-loaded $\mathrm{CH}$ MPs; $\mathrm{CH}$ films; peptide $\mathrm{CH}$ films; $\mathrm{CH}$ films with $\mathrm{CH}$ MPs; $\mathrm{CH}$ films with peptide-loaded CH MPs) assured high cell viability. Hence, the cytotoxicity could be categorized as class 1 (Figure 3), which demonstrates that the $\mathrm{CH}$ films with peptide-loaded $\mathrm{CH}$ MPs have excellent cell biocompatibility. The results were obtained in conformity with other studies in which chitosan did not interfere with cell viability [20]. 


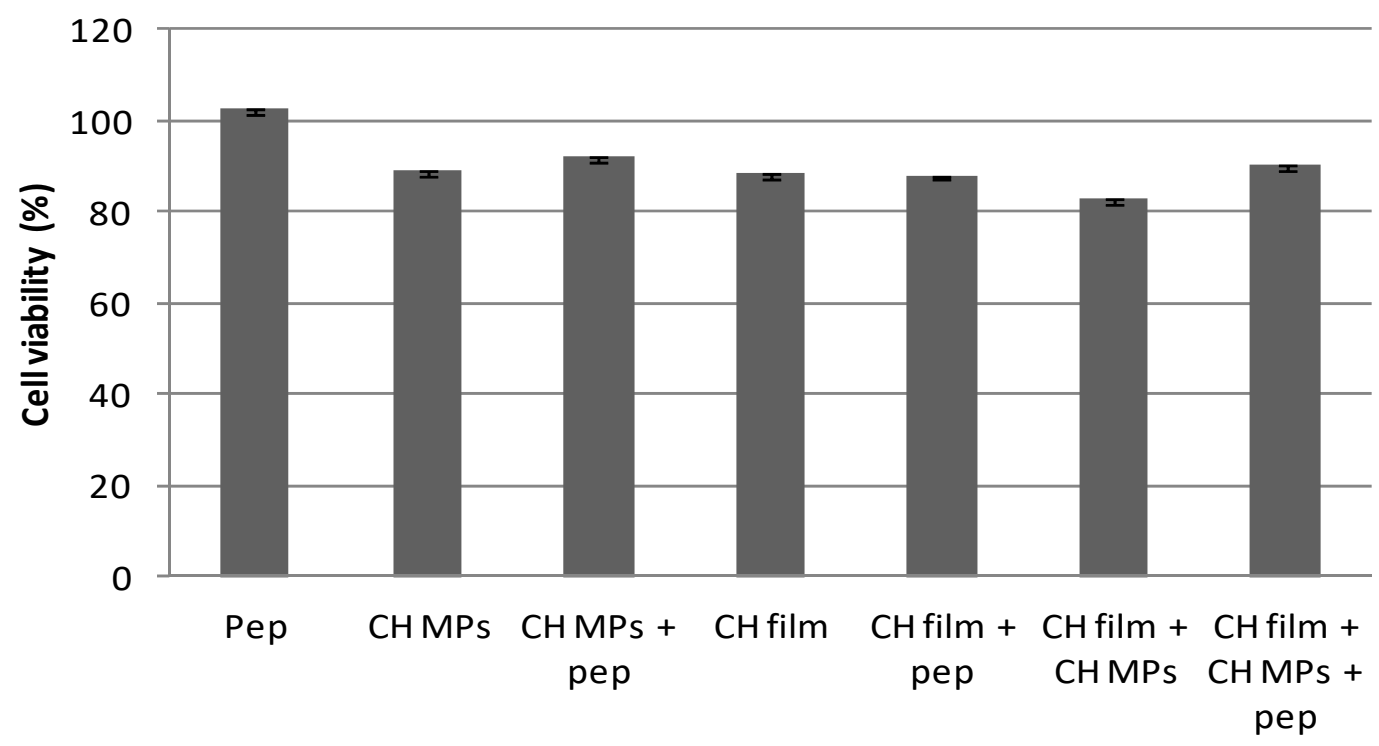

Experimental conditions

Figure 3. Cell viability under effect of peptide $(5 \mu \mathrm{g} / \mathrm{mL})$; $\mathrm{CH} \mathrm{MPs}, \mathrm{CH}$ film and $\mathrm{CH}$ MPs incorporated into $\mathrm{CH}$ film with and without peptide $(5 \mu \mathrm{g} / \mathrm{mL})$, measured by MTT assay and expressed as the mean $\pm \mathrm{SD}(n=5)$.

\section{Conclusions}

The present study presented an innovative approach focused on combining $\mathrm{CH}$ MPs with $\mathrm{CH}$ films as delivery systems for the potential administration of peptide/proteins across the buccal mucosa. CH MPs loaded with antihypertensive peptide were successfully prepared using the ionic gelation method and showed desirable pharmaceutical properties including small size and high $\mathrm{AE} \%$. Encapsulation of the peptide into CH MPs enhanced the peptide stability and the controlled release.

Chitosan MPs with peptide were incorporated into $\mathrm{CH}$ films by solvent casting. The method used for film production is practical, simple, safe and reproducible. These mucoadhesive films have the ability to enhance the penetration of large molecules across the oral mucosal surface and have a protective effect of the MPs, which can elevate the peptide bioavailability.

Therefore, the developed system has ample potential for the delivery of drugs or/and bioactive molecules (bioactive peptides) by the oral route. It constitutes a good solution for the oral delivery of antihypertensive small peptides, and might be a potential strategy for hypertension control in the future.

Author Contributions: All authors contributed for this paper. P.B. and P.C. contributed equally to the paper in investigation and writing. A.R.M.; B.S. and M.P. writing and review. M.P. was the supervisor.

Funding: This research was funded by national funds from FCT through project PTDC/BBB-NAN/3249/2014.

Acknowledgments: The authors acknowledge the support granted by national funds from FCT through project PTDC/BBB-NAN/3249/2014.

Conflicts of Interest: The authors declare no conflict of interest.

\section{References}

1. Batista, P.; Castro, P.M.; Madureira, A.R.; Sarmento, B.; Pintado, M. Recent insights in the use of nanocarriers for the oral delivery of bioactive proteins and peptides. Peptides 2018, 101, 112-123. [CrossRef] [PubMed]

2. Giovino, C.; Ayensu, I.; Tetteh, J.; Boateng, J.S. An integrated buccal delivery system combining chitosan films impregnated with peptide loaded PEG-b-PLA nanoparticles. Colloids Surf. B Biointerfaces 2013, 112, 9-15. [CrossRef] [PubMed] 
3. Patel, A.; Cholkar, K.; Mitra, A.K. Recent developments in protein and peptide parenteral delivery approaches. Ther. Deliv. 2014, 5, 337-365. [CrossRef] [PubMed]

4. Yu, M.; Wu, J.; Shi, J.; Farokhzad, O.C. Nanotechnology for protein delivery: Overview and perspectives. J. Control. Release 2016, 240, 24-37. [CrossRef] [PubMed]

5. Moutinho, C.G.; Matos, C.M.; Teixeira, J.A.; Balcão, V.M. Nanocarrier possibilities for functional targeting of bioactive peptides and proteins: State-of-the-art. J. Drug Target. 2012, 20, 114-141. [CrossRef] [PubMed]

6. Brandelli, A.; Daroit, D.J.; Corrêa, A.P.F. Whey as a source of peptides with remarkable biological activities. Food Res. Int. 2015, 73, 149-161. [CrossRef]

7. Tavares, T.; del Mar Contreras, M.; Amorim, M.; Pintado, M.; Recio, I.; Malcata, F.X. Novel whey-derived peptides with inhibitory effect against angiotensin-converting enzyme: In vitro effect and stability to gastrointestinal enzymes. Peptides 2011, 32, 1013-1019. [CrossRef]

8. Ahmed, T.A.; Aljaeid, B.M. Preparation, characterization, and potential application of chitosan, chitosan derivatives, and chitosan metal nanoparticles in pharmaceutical drug delivery. Drug Des. Dev. Ther. 2016, 10, 483-507. [CrossRef]

9. Morishita, M.; Peppas, N.A. Is the oral route possible for peptide and protein drug delivery? Drug Discov. Today 2006, 11, 905-910. [CrossRef]

10. Castro, P.M.; Fonte, P.; Sousa, F.; Madureira, A.R.; Sarmento, B.; Pintado, M.E. Oral films as breakthrough tools for oral delivery of proteins/peptides. J. Control. Release 2015, 211, 63-73. [CrossRef]

11. Rossi, S.; Sandri, G.; Caramella, C.M. Buccal drug delivery: A challenge already won? Drug Discov. Today Technol. 2005, 2, 59-65. [CrossRef]

12. Mahato, R.I.; Narang, A.S.; Thoma, L.; Miller, D.D. Emerging trends in oral delivery of peptide and protein drugs. Crit. Rev. ${ }^{\text {TM }}$ Ther. Drug Carr. Syst. 2003, 20. [CrossRef]

13. Shaji, J.; Patole, V. Protein and Peptide Drug Delivery: Oral Approaches. Indian J. Pharm. Sci. 2008, 70, 269-277. [CrossRef] [PubMed]

14. Giovino, C.; Ayensu, I.; Tetteh, J.; Boateng, J.S. Development and characterisation of chitosan films impregnated with insulin loaded PEG-b-PLA nanoparticles (NPs): A potential approach for buccal delivery of macromolecules. Int. J. Pharm. 2012, 428, 143-151. [CrossRef] [PubMed]

15. Castro, P.M.; Fonte, P.; Oliveira, A.; Madureira, A.R.; Sarmento, B.; Pintado, M.E. Optimization of two biopolymer-based oral films for the delivery of bioactive molecules. Mater. Sci. Eng. C 2017, 76, 171-180. [CrossRef]

16. Andrade, F.; Antunes, F.; Vanessa Nascimento, A.; Baptista da Silva, S.; das Neves, J.; Ferreira, D.; Sarmento, B. Chitosan formulations as carriers for therapeutic proteins. Curr. Drug Discov. Technol. 2011, 8, 157-172. [CrossRef] [PubMed]

17. Boateng, J.S.; Stevens, H.N.; Eccleston, G.M.; Auffret, A.D.; Humphrey, M.J.; Matthews, K.H. Development and mechanical characterization of solvent-cast polymeric films as potential drug delivery systems to mucosal surfaces. Drug Dev. Ind. Pharm. 2009, 35, 986-996. [CrossRef]

18. Ngo, D.-H.; Vo, T.-S.; Ngo, D.-N.; Kang, K.-H.; Je, J.-Y.; Pham, H.N.-D.; Byun, H.-G.; Kim, S.-K. Biological effects of chitosan and its derivatives. Food Hydrocoll. 2015, 51, 200-216. [CrossRef]

19. Wang, J.J.; Zeng, Z.W.; Xiao, R.Z.; Xie, T.; Zhou, G.L.; Zhan, X.R.; Wang, S.L. Recent advances of chitosan nanoparticles as drug carriers. Int. J. Nanomed. 2011, 6, 765.

20. Caetano, L.; Almeida, A.; Gonçalves, L. Effect of Experimental Parameters on Alginate/Chitosan Microparticles for BCG Encapsulation. Mar. Drugs 2016, 14, 90. [CrossRef]

21. Verma, S.; Kumar, N.; Sharma, P.K. Buccal film: An advance technology for oral drug delivery. Adv. Biol. Res. 2014, 8, 260-267.

22. FDA, Food and Drug Administration. GRAS Notice Inventory. Available online: https://www.fda.gov/ Food/IngredientsPackagingLabeling/GRAS / (accessed on 17 January 2019).

23. Calvo, P.; Remunan-Lopez, C.; Vila-Jato, J.L.; Alonso, M. Novel hydrophilic chitosan-polyethylene oxide nanoparticles as protein carriers. J. Appl. Polym. Sci. 1997, 63, 125-132. [CrossRef]

24. Araújo, F.; Shrestha, N.; Shahbazi, M.-A.; Fonte, P.; Mäkilä, E.M.; Salonen, J.J.; Hirvonen, J.T.; Granja, P.L.; Santos, H.A.; Sarmento, B. The impact of nanoparticles on the mucosal translocation and transport of GLP-1 across the intestinal epithelium. Biomaterials 2014, 35, 9199-9207. [CrossRef] [PubMed] 
25. Castro, P.M.; Baptista, P.; Madureira, A.R.; Sarmento, B.; Pintado, M.E. Combination of PLGA nanoparticles with mucoadhesive guar-gum films for buccal delivery of antihypertensive peptide. Int. J. Pharm. 2018, 547, 593-601. [CrossRef] [PubMed]

26. Cardelle-Cobas, A.; Madureira, A.R.; Costa, E.; Barros, R.; Tavaria, F.K.; Pintado, M.E. Development of Oral Strips Containing Chitosan as Active Ingredient: A Product for Buccal Health. Int. J. Polym. Mater. Polym. Biomater. 2015, 64, 906-918. [CrossRef]

27. Nielsen, H.M.; Rassing, M.R. TR146 cells grown on filters as a model of human buccal epithelium: IV. Permeability of water, mannitol, testosterone and $\beta$-adrenoceptor antagonists. Comparison to human, monkey and porcine buccal mucosa. Int. J. Pharm. 2000, 194, 155-167. [CrossRef]

28. Portero, A.; Remuñán-López, C.; Nielsen, H.M. The potential of chitosan in enhancing peptide and protein absorption across the TR146 cell culture model-An in vitro model of the buccal epithelium. Pharm. Res. 2002, 19, 169-174. [CrossRef] [PubMed]

29. Ahsan, S.M.; Thomas, M.; Reddy, K.K.; Sooraparaju, S.G.; Asthana, A.; Bhatnagar, I. Chitosan as biomaterial in drug delivery and tissue engineering. Int. J. Biol. Macromol. 2017, 110, 97-109. [CrossRef]

30. Jain, A.; Thakur, K.; Sharma, G.; Kush, P.; Jain, U.K. Fabrication, characterization and cytotoxicity studies of ionically cross-linked docetaxel loaded chitosan nanoparticles. Carbohydr. Polym. 2016, 137, 65-74. [CrossRef]

31. Shah, U.; Joshi, G.; Sawant, K. Improvement in antihypertensive and antianginal effects of felodipine by enhanced absorption from PLGA nanoparticles optimized by factorial design. Mater. Sci. Eng. C 2014, 35, 153-163. [CrossRef]

32. Oliveira, P.M.; Matos, B.N.; Pereira, P.A.; Gratieri, T.; Faccioli, L.H.; Cunha-Filho, M.S.; Gelfuso, G.M. Microparticles prepared with 50-190 kDa chitosan as promising non-toxic carriers for pulmonary delivery of isoniazid. Carbohydr. Polym. 2017, 174, 421-431. [CrossRef] [PubMed]

33. Walke, S.; Srivastava, G.; Nikalje, M.; Doshi, J.; Kumar, R.; Ravetkar, S.; Doshi, P. Fabrication of chitosan microspheres using vanillin/TPP dual crosslinkers for protein antigens encapsulation. Carbohydr. Polym. 2015, 128, 188-198. [CrossRef] [PubMed]

34. Sipoli, C.C.; Santana, N.; Shimojo, A.A.M.; Azzoni, A.; de la Torre, L.G. Scalable production of highly concentrated chitosan/TPP nanoparticles in different $\mathrm{pHs}$ and evaluation of the in vitro transfection efficiency. Biochem. Eng. J. 2015, 94, 65-73. [CrossRef]

35. Jain, R.A. The manufacturing techniques of various drug loaded biodegradable poly (lactide-co-glycolide)(PLGA) devices. Biomaterials 2000, 21, 2475-2490. [CrossRef]

36. Tao, C.; Huang, J.; Lu, Y.; Zou, H.; He, X.; Chen, Y.; Zhong, Y. Development and characterization of GRGDSPC-modified poly (lactide-co-glycolide acid) porous microspheres incorporated with protein-loaded chitosan microspheres for bone tissue engineering. Colloids Surf. B Biointerfaces 2014, 122, 439-446. [CrossRef] [PubMed]

37. Yu, T.; Zhao, S.; Li, Z.; Wang, Y.; Xu, B.; Fang, D.; Wang, F.; Zhang, Z.; He, L.; Song, X. Enhanced and Extended Anti-Hypertensive Effect of VP5 Nanoparticles. Int. J. Mol. Sci. 2016, 17, 1977. [CrossRef] [PubMed]

38. Dammak, I.; Bittante, A.M.Q.B.; Lourenço, R.V.; do Amaral Sobral, P.J. Properties of gelatin-based films incorporated with chitosan-coated microparticles charged with rutin. Int. J. Biol. Macromol. 2017, 101, 643-652. [CrossRef] [PubMed]

39. Chen, H.; Hu, X.; Chen, E.; Wu, S.; McClements, D.J.; Liu, S.; Li, B.; Li, Y. Preparation, characterization, and properties of chitosan films with cinnamaldehyde nanoemulsions. Food Hydrocoll. 2016, 61, 662-671. [CrossRef]

40. Ojagh, S.M.; Rezaei, M.; Razavi, S.H.; Hosseini, S.M.H. Development and evaluation of a novel biodegradable film made from chitosan and cinnamon essential oil with low affinity toward water. Food Chem. 2010, 122, 161-166. [CrossRef]

41. Park, S.-I.; Zhao, Y. Incorporation of a high concentration of mineral or vitamin into chitosan-based films. J. Agric. Food Chem. 2004, 52, 1933-1939. [CrossRef] [PubMed]

42. Frindy, S.; Primo, A.; el kacem Qaiss, A.; Bouhfid, R.; Lahcini, M.; Garcia, H.; Bousmina, M.; El Kadib, A. Insightful understanding of the role of clay topology on the stability of biomimetic hybrid chitosan-clay thin films and $\mathrm{CO}_{2}$-dried porous aerogel microspheres. Carbohydr. Polym. 2016, 146, 353-361. [CrossRef] [PubMed] 
43. Chonkar, A.D.; Rao, J.V.; Managuli, R.S.; Mutalik, S.; Dengale, S.; Jain, P.; Udupa, N. Development of fast dissolving oral films containing lercanidipine $\mathrm{HCl}$ nanoparticles in semicrystalline polymeric matrix for enhanced dissolution and ex vivo permeation. Eur. J. Pharm. Biopharm. 2016, 103, 179-191. [CrossRef] [PubMed]

44. Aguilar, K.C.; Tello, F.; Bierhalz, A.C.; Romo, M.G.G.; Flores, H.E.M.; Grosso, C.R. Protein adsorption onto alginate-pectin microparticles and films produced by ionic gelation. J. Food Eng. 2015, 154, 17-24. [CrossRef]

45. Irfan, M.; Rabel, S.; Bukhtar, Q.; Qadir, M.I.; Jabeen, F.; Khan, A. Orally disintegrating films: A modern expansion in drug delivery system. Saudi Pharm. J. 2016, 24, 537-546. [CrossRef] [PubMed]

46. Tang, C.; Guan, Y.-X.; Yao, S.-J.; Zhu, Z.-Q. Preparation of ibuprofen-loaded chitosan films for oral mucosal drug delivery using supercritical solution impregnation. Int. J. Pharm. 2014, 473, 434-441. [CrossRef] [PubMed]

47. US Food and Drug Administration. American Guidance for Industry: Orally Disintegrating Tablets; US Food and Drug Administration: Washington, DC, USA, 2008.

48. Dahiya, M.; Saha, S.; Shahiwala, A.F. A review on mouth dissolving films. Curr. Drug Deliv. 2009, 6, 469-476. [CrossRef] [PubMed]

49. Shi, R.; Zhu, A.; Chen, D.; Jiang, X.; Xu, X.; Zhang, L.; Tian, W. In vitro degradation of starch/PVA films and biocompatibility evaluation. J. Appl. Polym. Sci. 2010, 115, 346-357. [CrossRef]

(C) 2019 by the authors. Licensee MDPI, Basel, Switzerland. This article is an open access article distributed under the terms and conditions of the Creative Commons Attribution (CC BY) license (http://creativecommons.org/licenses/by/4.0/). 